\title{
Moments of Discomfort: Poststructuralist Reflexivity and Researcher Subjectivity
}

\begin{abstract}
This article presents poststructural reflexivity as a way to both deconstruct the performativity of one's own research practice and consider how researcher subjectivity is constituted within the research process. I present two vignettes as moments of discomfort conducting research 'in the field' which I argue create a sense of unease when shifting subjectivities and regimes of power become more visible. I draw upon Foucauldian Discourse Analysis as a tool of poststructural reflexivity to illustrate discursive regimes through which we become gendered subjects. The article illustrates the usefulness of poststructural reflexivity as a way to consider the performative effect of research and regimes of power which impact our ways of seeing and being in the world.
\end{abstract}

Key words: Poststructuralism, reflexivity, Foucauldian Discourse Analysis, subjectivity, performativity 


\section{INTRODUCTION}

Reflexivity is well established as a core practice within qualitative and particularly feminist research (Bott, 2010; Finlay, 2002) where the researcher seeks to situate themselves within the research as a way to 'explore and expose the politics of representation' (Pillow, 2003: 176). Feminist versions of reflexivity (see for example Reinharz \& Davidman, 1992) have sought to address power balances between researchers and participants, indeed Wolf (1990: 132) argues 'before reflexivity was a trendy term, feminists were examining 'process' in our dealings with one another - questioning the use of power and powerlessness $[\ldots]$ evaluating the responsibilities we bore towards one another, and so on'. As Finlay (2002) highlights, the question is not so much whether there is a need for reflexivity, more how should it be done, with a danger that the researcher falls into a 'swamp of interminable self-analysis and self-disclosure' (Finlay, 2002: 212). Furthermore, critics highlight how reflexivity is often presented as a solution to representation whereby the researcher engages in a process of self-reflection thereby validating the knowledge through reflexivity as a 'tool of methodological power' (Lynch, 2000; Pillow, 2003: 192; see also). Following Pillow (2003) and Dosekun (2015), within this article we offer a poststructuralist approach to reflexivity which is a form of 'uncomfortable reflexivity' where the goals are not to validate or provide neat solutions, rather to 'confound and interrupt [...] to resist regimes of truth' (Dosekun, 2015: 436).

The poststructuralist turn recognised that research in itself constitutes its subjects and objects performatively (Davies et al., 2004; Dosekun, 2015; Youdell, 2006). If performativity is the 'reiterative and citational practice by which discourse produces the effects that it name' (Butler, 2011: xii), the discursive practice of research through naming and counting performatively brings objects or subjects into being so that they appear to have existed prior rather than being a 
performative effect of the research (Dosekun, 2015). Poststructuralist reflexivity focuses therefore on 'not who the researcher and research are but how they are reproduced in these terms' (Youdell, 2006: 63). Hence poststructuralism proposes a subjectivity that is continually being reconstituted in discourse every time we speak (Weedon, 1997: 32) and poststructural research a matter of deconstructing the performativity of one's research practice. Yet as Dosekun (2015: 436) highlights, 'complex questions remain about how one is to actually 'do reflexivity' or 'be reflexive', especially in line with poststructural theoretical principles'.

The aim of this paper is predominantly methodological. I draw on poststructuralist practices applied to the 'messy' work of reflexivity to bring to the fore power within the research and subsequent representations (Pillow, 2003). To do this, I present two vignettes from my doctoral research experience which created a sense of discomfort. I argue that it is in this space of discomfort that subjectivities become more visible and are played out through discursive regimes where the performativity of gender renders subjects as viable (Butler, 1990). Drawing upon Foucauldian Discourse Analysis; which considers discourses which legitimate power relations, make sense of ways of being and are so entrenched that they appear to have become 'common sense' (Willig, 2013), I argue that turning poststructuralist analysis back in on the researcher as a form poststructural reflexivity illuminates regimes of truth and power but also allows the researcher to consider how their subjectivity is constituted within the research process.

The paper is structured as follows. Firstly, I present an understanding of feminist poststructuralism particularly in relation to the performativity of gender. I then present my methodological approach drawing on principles of Foucauldian Discourse Analysis applied as a tool of reflexivity before discussing two vignettes as examples of uncomfortable reflexivity in my research of a bank and beauty company. Finally, I offer a discussion of poststructural reflexivity as way to consider 
researcher subjectivities and positionality within the research process itself. This paper therefore makes a contribution to our methodological understanding of the challenges of doing poststructural reflexivity and the opportunities for considering power and performativity within feminist research practice.

\section{POSTSTRUCTURALISM AND GENDERED SUBJECTIVITIES}

The poststructural approach considers gender as a social practice; as something we 'do' rather than something we 'are' (Bruni, Gherardi, \& Poggio, 2005; Martin, 2003; Poggio, 2006; Pullen, 2006). While this is also true of ethnomethodological approaches such as West and Zimmerman (1987) conceptualisation of 'doing gender', poststructuralists hold a more radical position suggesting that gender is not just something that we do or perform but that the performance of gender brings us into being (Tyler, 2012).

West and Zimmerman's (1987) model of doing gender suggests that individuals perceive the essential characteristics of feminine and masculine as existing separately to context or situation. Thus societal members view the existence of two genders, however these are created through interaction rather than a priori (Kelan, 2010). This shifts the focus from an essentialist view of gender as a binary biological concept to seeing gender as socially constructed, an accomplishment which is conducted within social and cultural contexts. However, it is a 'situated doing, carried out in the virtual or real presence of others who are presumed to be oriented to its production' (West \& Zimmerman, 1987: 126); therefore gender is created and recreated through interactions with others (Gherardi, 1994). Gender thus becomes 'the activity of managing situated conduct in light of normative conceptions of attitudes and activities appropriate from one's sex category' 
(West \& Zimmerman, 1987: 127). When individuals are 'doing gender', they are accountable to the audience to do gender in line with normative beliefs; in other words they are at 'risk of gender assessment' (West \& Zimmerman, 1987: 136).

In contrast, the poststructural approach to gender is drawn predominantly from the work of Judith Butler (1990, 2004). Butler (1990) sees gender not to be the expression of pre-given natural traits, but rather as becoming ritualised through constant repetition therefore making it appear natural (Tyler, 2012). Thus for Butler (1990: 25), gender and the gender binary is constructed discursively and 'gender is not a noun, but neither is it a set of free-floating attributes...gender is always a doing'.

Butler (1990) developed the notion of the performativity of gender which is much contested and difficult to define with certainty as it is evolves and shifts as a concept over the course of her writing (Salih, 2002). Butler (1990) argues that gender is performatively accomplished through 'a repeated stylization of the body' and a multitude of micro-acts that occur within a regulatory framework which 'congeal over time to produce the appearance of a substance, of a natural sort of being' (Butler, 1990: 33). Our gender subjectivities are therefore not something we are born or socialised into, rather we are performatively constituted as women or man through discourse (Gond, Cabantous, Harding, \& Learmonth, 2016). Performativity does not suggest that gender is a performance as this presupposes a subject who is doing that performance, rather Butler suggests that subjectivities are thus the effect of discourse, through the 'reiterative and citational practice by which the discourse effects what it names...[and] the recitative power of discourse to produce the phenomena that it regulates and constrains' (Butler, 2011: 3). This is counter-intuitive and much challenged (Kelan, 2010; Tyler, 2012). 
Butler (1990) draws heavily on Foucault's formation of discourses as groups of statements governing the way we understand and perceive historical moments, thus gender is constructed discursively within these historical contexts and discourses provide positions which subjects can adopt. One of these discursive regimes Butler (1990) describes is the heterosexual matrix where gender, sex and desire are organised schematically in a way that privileges hegemonic masculinity. Enacting gender in line with the heterosexual matrix involves 'un/doing' gender (Butler, 2004) where for individuals to be recognised as 'viable' subjects they must operate within and maintain socially intelligible norms (Butler, 1990). In other words, we have to be readable within the norm to exist as human beings (Butler, 2004). Those that are unable to live within these norms risk being forced to live a life not worth living (Pullen \& Knights, 2007); they are 'undone', thus losing their sense of self and excluded socially.

This un/doing has implications for the performative production of gender within organisations with Butler (1990) arguing we should be looking at how the category 'woman' is produced and constituted within power structures thus rejecting the critical feminist approach which seeks to consider how to overthrow these power structures. Drawing on a Foucauldian notion of discourse, Butler suggests the need to consider how discourses function, the political aim they fulfil, and how the subject is constructed as an 'effect' of institutions, practices and discourses (Butler, 1990). Simpson and Lewis (2007: 16) summarise the poststructural feminist approach to 'doing gender' suggesting that for poststructuralists, 'gender is performative in that feminine and masculine are not what we are or traits we have but effects we produce by way of what we do'. As Tyler (2012: 13) argues 'for those influenced by a postmodern understanding of the self, gender is an ongoing process, one that has to be continually re-enacted and re-inscribed in accordance with the cultural norms defining masculinity and femininity at any given time, and in any given context'. 
In summary, while the ethnomethodological approach to doing gender focuses on how gender is done in interactions, the poststructuralist approach to doing gender focuses on the formation of subjects through discourse such that gender is an effect. I next turn to consider poststructural methodologies particularly Foucauldian Discourse Analysis as a way to make sense of poststructural reflexivity, discourse and power.

\section{POSTSTRUCTURAL METHODOLOGIES AND FOUCAULDIAN DISCOURSE}

\section{ANALYSIS}

Poststructuralists are critical of realist social science approaches that claim an existence beyond the researcher's observations and their subjects, rather seeing individual subjectivities as created through social and discursive practices (Davies \& Gannon, 2011). Post-structuralism typically does not draw on a set of practices that can be considered a 'method' (Gannon \& Davies, 2012), rather poststructural theory, particularly through the work of Michel Foucault, turns to discourse as the primary site for analysis. For Foucault, discourses are complex intertwined connections of being, thinking, and acting. They are constantly changing; historically, culturally, temporally and spatially located. Individuals are constituted within this multitude of discursive practices; there is 'no pre-discursive rational self, existing outside of or apart from discourse' (Gannon \& Davies, 2012: 74).

Discourse extends beyond language to other forms of textual analysis which can be on a macrolevel, for example, capitalism, feminism, Marxism etc., or at a more micro level incorporating interviews or indeed bodies and space. Butler (1997) for example argues that the body is a site of discourse stating 'one is not simply a body, but, in some very key sense, one does one's body" 
(Butler, 1997: 404). 'Deconstructing' these texts by taking them apart and showing how they present us provides insight into the way discourse constructs our experience and thus enable us to challenge it (Burr, 2015). As Burr (2015) highlights, while this has been typically been associated with discursive psychology (see for example Potter, 1996), much research application today falls under Foucauldian Discourse Analysis. Foucauldian Discourse Analysis (FDA) focuses on the availability of discursive resources within a particular context which make available certain ways of being and seeing in the world (Willig, 2013). Discourses are 'sets of statements that construct objects and an array of subject positions' (Parker, 1994: 245) which, when taken up, have consequences for subjectivity and experience. Dominant discourses privileged those with power and create social realities that become 'common sense'; difficult to see as they are so ingrained.

There are no agreed upon conceptual tools to guide FDA (Burr, 2015) although (Parker, 1992) provides 20 steps of discourses analysis, others such as Kendall and Wickham (1999) have fewer steps but, as Willig (2013) argues, require more of a conceptual understanding of Foucault's methods. We draw on Willig's (2013) 6 step process of FDA. Whilst this does not provide a full analysis in the Foucauldian sense by reflecting the history and genealogy of discourses over time, it does provide insight into the availability of subject positions and subsequent subjectivities and experience. Willig's (2013) six steps include: Identifying discursive constructions (highlighting instances where the discursive object is referenced); locating discourses (how do the different constructions differ and how does this fit within wider discourses): action orientation (what do these constructions achieve and what is their effect), positionings (what subject positions are made available by the discourse), practice (what can be said and done from within these subject positions); and subjectivity (what can be thought or felt from these subject positions). 
FDA selects any site of meaning as a form of text for analysis, thus a multitude of sources beyond speech can be used as a textual analysis for example, adverts, bodies, architecture. As Gannon and Davies (2012: 74) highlight "there are no "right" research methods that will produce a reality that lies outside of the texts produced in the research process because reality does not pre-exist the discursive and constitutive work that is of interest to post-structural writers'. I have selected vignettes taken from my doctoral research which I recognise to be discourses in themselves and therefore possible to apply a poststructuralist analysis to these discourses as a means of researcher reflexivity. Before presenting my vignettes, I first position these within the research context and background.

\section{RESEARCH CONTEXT AND BACKGROUND}

The vignettes draw upon research conducted at two organisations as part of my doctoral research into femininities and neoliberal discourses within organisations. The first organisation I studied is a multi-national bank with its head office in the UK. Twenty interviews were conducted with women who ranged from Associate Vice President, a junior middle management position, through to Managing Director; a senior position within the bank. The majority of interviews were conducted face-to-face although some took place over the phone due to geographically constraints. The interviews typically lasted an average of 50 minutes and were recorded and transcribed verbatim. Alongside the interviews, I kept a detailed research diary where observations, feeling and reflections were captured after each interview and during the research process as a whole.

The second organisation I draw upon is a beauty network marketing company. Network marketing is a business structure where distributors are recruited to work as freelancers selling the products 
to clients whilst also seeking to grow their own teams of distributors (Biggart, 1989). Network marketing is precarious work with many distributors failing to make a living wage (Shade, 2018). The 16 women I interviewed had all reached higher 'pin titles', the name given to ranks based on income generated, thus were successful within network marketing terms. In addition to the interviews, I also conducted around 40 hours of participant observation by becoming a distributor and attending sales meetings, team meetings and networking events. Again, a detailed research diary and observation notes were taken which captured observations, conversations and reflexive thoughts during the research process. Following Wolfinger (2002), a comprehensive approach to taking field notes was adopted through capturing the sequence of events. Yet I acknowledge that these notes inevitably reflect 'background knowledge or tacit beliefs' (Wolfinger, 2002: 93) as data is constructed through those events and conversations which are captured and those which are not.

The two vignettes I have selected are adapted from my research diary and notes taken as the events happen and used as a way to place the researcher as an actor in the 'play' (Butler, 1997; Humphreys, 2005; Liu, 2018). Thus the vignettes are used as a way to provide a 'vivid portrayal of the conduct of everyday life' (Erickson, 1986: 149). The vignettes are selected as examples of 'uncomfortable reflexivity' (Pillow, 2003: 193) as their purpose is not to claim better representation of the research participants or indeed us as researchers but rather as they left me with a sense of unease. Therefore these vignettes as not selected to represent reflexivity as a 'tool of methodological power' (Pillow, 2003: 192) but rather as examples of the 'messy' realities of organisational research where subjectivity is reconstituted in discourse (Dosekun, 2015; Weedon, 1997). Thus these vignettes are not presented as the 'truth' of the events as the goal is not to presume the discovery of truth (Cunliffe \& Haynes, 2011; Liu, 2018) but instead have an element 
of what Liu (2018) refers to as fictualisation; told in a way that captures the feelings and emotional experiences. Names in the vignettes have been altered to maintain anonymity.

\section{MOMENTS OF DISCOMFORT AND SHIFTING SUBJECTIVITIES}

I turn to present two vignettes which have been adapted from my research notes and are therefore presented in the first person. Thus the 'text' is the reflexive notes of these research experiences, the feelings and shifting subjectivities. Both these instances are chosen as they personally resonated as something uncomfortable, they had a certain significance and sense of heightened awareness. I first present these reflexive vignettes and then parse these vignettes through a FDA lens to consider questions of power and subjectivities.

\section{First meeting with the Bank project sponsor 'Simon'}

Access to the bank and the women managers comes through a colleague who puts me in contact with 'Simon', a Director at the bank, who she describes as 'supportive of promoting more women within his team'. After an email exchange we arrange to meet at his office. The emails are brief and formal without niceties: just 'Melissa' in the initial line, no 'Dear' or 'Hi', 'kind regards' etc. I copy this approach in my email exchange back but it feels odd for me and I imagine Simon to be austere and perfunctory.

On the agreed meeting day, I'm met at reception by the Director's personal assistant who leads me up to one of the higher floors in the building. We make small talk in the lift about the traffic. The Directors office is situated at the far end of an open plan floor in a glass box along one of the 
far walls. Why do all offices look the same and why do managers sit in glass boxes as if they are on display? As I walk across the open plan area I notice firstly that there is a balance of men and women, I'm surprised as I was envisaging more men, and secondly that people are casually dressed. It is 'dress down Friday' and I'm wearing a suit which I dragged from the back of my wardrobe earlier. I feel conspicuously overdressed and hence very visible as I walk through this area. In my heels (which I never normally wear, why today?) I'm 5ft 10 which increases my sense of visibility. I feel like I am play-acting at this role, like a caricature corporate women, a costume I used to blend in but then I got caught out.

I'm shown into the office by the PA and Simon comes round the desk to shake my hand. I see him look slightly surprised for a minute and I wonder if I'm not what he expected. So what did he expect? He's about the same age as me but shorter than me and everything about him is precise and pristine. The conversation somehow quickly turns to his career and he is surprisingly open and unguarded. He tells me that the bank 'isn't for him'; he's been told he needs to be more 'cut throat' to get ahead. Simon is ex-military, white, married and personifies a form of hegemonic masculinity which makes me wonder what 'more cut-throat' looks like in this environment if he doesn't fit the mould. I wasn't expecting the Director to start telling me how unhappy he is at the bank and I feel like part coach, part sympathetic wife. On one level I feel flattered as if this validates my credibility to be there, on the other I feel a degree of intimacy which makes me feel uncomfortable. As I smile and nod sympathetically I feel very uncomfortable, there is something within the exchange that creates a sense of unease. I mention the term 'gender champions' and he picks this up, self-identifying as one and reiterating a couple of times that is how he sees himself. 
After discussing my research, he opens his office door and beckons three women from his team into the office and introduces them. They are all at AVP and VP level so report directly into him. He explains the project to them and that I will be in contact. I am mute as he explains it and they are too. We all look at him, smiling and passive. I note that he claims authority in this situation. He asserts himself as the facilitator and enabler of this conversation and my access to the women. The meeting is closed with him saying he will forward the emails of the women to me. It's clear he will be the point of contact and enabler of this research and I feel powerless without his support.

This experience in my research resonated as a moment of discomfort; it left a sense of unease which was carried beyond the meeting. Using the principles of FDA to examine this vignette as a text offers insight into the discourses that produce the effect that it names (Butler, 2011) thus to consider why this moment created such discomfort. Reading the vignette as a text allows an opportunity to turn one's reflective gaze back in on itself; to focus on discourse and its constitutive effect.

In reading the text as a poststructural performance, I see discourses of power and hegemonic masculinity which speaks to Butler (2004) heterosexual matrix where individuals must operate within socially intelligent norms to be recognised as viable (Butler, 1990). Hegemonic masculinity is a dominant discourse which privileges a version of reality which legitimates power relations (Willig, 2013), for example; the architecture of the office, the long walk to the glass box, the desk behind which the Director sits, the curt and perfunctory email exchange. These are discursive objects of power which render a power dynamic through which I feel both subordinate and Other an embodied feminine researcher within the masculine corporate setting. I do not belong. This

\footnotetext{
${ }^{1}$ AVP is Associate Vice President, a junior manager role and VP is Vice President, the subsequent level of promotion. These roles carry line management and budget responsibility.
} 
sense of otherness is expressed through my dress which is selected as a means to blend into what I perceived to be appropriate from my previous experiences working as a management consultant. Davies et al. (2006: 99) suggest that where subjection and mastery co-exist, 'co-existence is made starkly visible by the (un)expected interruption to the moment of mastery'. I recognise this here where my sense of mastery as a professional woman drawing on discourses of acceptable corporate dress (Kelan, 2013) is interrupted. I become undone (Butler, 2004) when 'dress-down Friday' and my height means I am visible and vulnerable.

A feeling of discomfort occurs with shifting discourses which create a sense of switching subjectivities. Kanter (1977) discusses how women are often positioned in stereotypical roles such as mother or seductress and I see similar discourses here. At points in the conversation, I feel like a sympathetic listening ear to the Director's problems; there is a sense of intimacy which creates discomfort through the performativity of the gender binary where my intelligibility as a women is a result of social norms and the heterosexual matrix (Butler, 2004). While it has been argued that there is a pluralization of gender which allows subjects to occupy multiple and shifting positions (Kelan, 2010), my discomfort comes exactly from the feeling that there is a lack of subject positions. The intimacy of hearing the Director's problems draws on discourses of femininity sympathetic, listening, and supportive - which presents a subject position from which it appears that opportunities for action are closed down; what can be said and done becomes limited. Thus the effect of this interaction is performative and my feminine subjectivity is an uncomfortable effect of this discourse.

When the other women are brought into the room, I feel a shift in discourse from being positioned as a sympathetic listening ear to a move in power where the Director positions himself as the enabler and facilitator of this fundamentally feminist piece of research. The women in the room 
are mute, I smile and nod agreeably and this creates unease. My subjectivity shifts from a form of femininity within the heterosexual matrix of sympathetic woman to mute subordinate with the Director as enabler of the research. There is a tension; I feel that I need the Director's approval to gain access to women in a corporate bank which feels insurmountable without the Director's help, yet here is a man governing this feminist research. Furthermore, in presenting himself as a 'gender champion', he draws on a patriarchal discourse and the gender binary where, on the one hand he is the paternalistic protector of the women who are in need of his help and support, but on the other he is the gatekeeper who can govern, monitor and control this. He is the gatekeeper and thus discomfort comes from this sense of powerless. As a researcher, what can be said and done within these subject positions feels very limited and my reluctance to adopt a subject position within discourse which identifies 'a location for persons within the structure of rights and duties for those that use that repertoire' (Davies \& Harre, 1999: 35) creates the unease and discomfort this experience leaves.

\section{Attending a Beauty Network Marketing distributor recruitment event}

During the early stages of research at the beauty network marketing company (NMO) I was invited by my main contact at the NMO (Louise) to a Saturday meeting in a local hotel. These events serve the dual purpose of training and a sales pitch as distributors invite guests so they can learn and be recruited into the business. I note in my diary that I am nervous about attending as I don't know what to expect having had no interaction with NMO's or beauty companies before. I imagine a room full of well-made up glamourous women and I worry about what to wear. I want to blend in 
and write in my diary 'I want to look feminine but not corporate' but I'm not actually sure what this looks like.

I meet Louise in the café area of the hotel. There are lots of women there, all kissing each other like old friends. When Louise introduces me to people, they kiss me on the cheek and tell me how exited they are that I am there which surprises me and leaves me unsure how respond. I feel like I want to believe them, but I wonder if they are just seeing me a potential customer? We go up to the room where music is playing - high impact, high energy music and people are talking loudly. I'm struck that there are men there, I was expecting all women. I'm also struck by the clothes the men are wearing, in my diary I write 'snappy dressers and the shoes!' One man, for example, has bright blue leather shoes with pony skin on the top part, while another man is dressed in a jacket of a vivid checked pattern. The women aren't the Instagram, Kim Kardashian-styled, glamourous women I expected; they are very diverse in terms of age and appearance, and Louise whispers to me that these women are 'serial entrepreneurs, savvy women'.

The guest speakers for the day are a husband and wife team who are 'blue diamonds', the NMO elite. Their presentation feels carefully scripted like a double act so that 'Izzie' is the bossy wife running the event and her husband 'Jay' is her comedy fall guy. Izzie is a tiny, glamorous woman in her early 30 's. She's wearing a white, tight dress quite similar to one a beautician would wear (strange on a cold November day) and towering Christian Louboutin heels. I feel dull and frumpy when I'm introduced to her.

Izzie leads the presentation and does $90 \%$ of the talking. Izzie describes her motivation to become involved in the NMO as giving her 'time with her kids' and Jay says it was 'the money' with a wink to the audience. Izzie gives an eye roll to the audience who laugh. Izzie appears to be the driving 
force and Jay is there to make the men feel comfortable. The presentation is laced with sexual innuendo and Jay shouts 'Yeah' at full volume whenever money is mentioned. There is a lot of pseudo-science with pictures of scientists flashed on the screen (all men) who invented these 'life changing' beauty products.

Izzie explains that when she was deciding whether to become a distributor she wanted to know more about the financial credibility of the company. She says 'I ask the one person I trusted most, I have real trust in my daddy'. She explains that her 'daddy' researched the business and explained it to her; 'my daddy knows what this is...I just say 'oh that's nice' (said with high childlike voice and big eyes). I feel my eyes flicking between Izzie and Jay and the audience and I wonder what they are all thinking? Later she talks about her son and cries. Jay is mute throughout this and offers no comfort when she cries. I feel both intrigued and uncomfortable watching this. Do other people see what I am seeing? Ifeel uneasy as if I am judging these women, and who am I to judge? Am I judging? I feel judgemental even though I'm there as an observer, I am a researcher. In critiquing what I see, am I not being a good feminist, a supporter of women?

After the pitch Louise introduces me and Anya; another of her 'guests' (potential distributors), to a team elite leader at the NMO. Anya is German, early 30's, married with a young child. I hover awkwardly on the outside of the conversation. Anya keeps apologising for her appearance and her 'no makeup face'. The team elite says, 'I love this woman, I can feel her energy'. I feel voyeuristic and uncomfortable. The next day Louise calls me, hugely enthusiastic, and asks me what I think. I tell her I really enjoyed it. I feel disingenuous.

I have selected this experience in my doctoral research as a moment of discomfort which left a legacy feeling of unease. Considering this discomfort through a FDA lens, there are dominant 
discourses which created tensions and disquiet. In line with other beauty NMO's (see for example Sullivan \& Delaney, 2017), the NMO I researched positions itself as an emancipatory force which frees women from ' $9-5$ ' occupations to enable them to earn money while balancing home and family life. When Louise whispers to me in a reverential way that the women are 'serial entrepreneurs, savvy business women' they are constituted as 'competence machines'(Foucault, 2008: 312) through an enterprising self discourse where individuals are free agents, working within the market to develop themselves as their own form of human capital. Yet this obscures the precarious and gendered nature of NMO work (Shade, 2018; Williams, Muller, \& Kilanski, 2012) and part of my discomfort comes from my growing knowledge of the organisational realities of NMO's. When my eyes flick between Izzie, Jay and the audience I have a sense of an illusion where potential distributors are 'sold' an experience with high energy music, symbols of success in the expensive clothes and dazzling shoes, and talk of balancing family life while earning significant commission. This creates a tension where on the one hand my silence and lack of challenge to this neoliberal illusion caste me as a co-conspirator and on the other, my critical observations and judgements 'hovering on the edge of conversations' make me feel like a failed feminist constructing power relations between myself as a researcher and the women. As Davies and Harre (1999: 35) suggest 'once having taken up a particular position as one's own, a person inevitably sees the world from the vantage point of that position and in terms of the particular images, metaphors, storylines and concepts which are made relevant within the particular discursive practice in which they are positioned'. Yet here I feel caught in the middle of two subject positions limited by what I feel can be said and done in either position. Subsequently I feel undone and unreadable within these subject positions (Butler, 2004). 
When I reflect on this event, I see a form of emphasised femininity as evident within this experience, it pervades as a dominant discourse which restricts the subject positions available and essentialises gender differences (Lewis, 2013; Lewis, Benschop, \& Simpson, 2017). Much of this revolves around Izzie and how she is constructed through discourse. When she talks about 'asking her Daddy' and uses a child-like voice, she is infantilised and positioned as incapable of understanding the financial side of the NMO business. Gill and Orgad (2015) discuss how infantilising metaphors become a mode of self-regulation that gives women the illusion of being in control while avoiding critiquing the structures which perpetuate gender inequalities. Here Izzie's 'daddy' references seem to go further than this; they validate her and make her acceptable as a viable subject within patriarchal discourse. Infantilising discourse constructs Izzie as a childlike woman who likes beauty products (read femininity) and refers financial matters (read masculinity) to her father. Thus infantilising becomes a form of protection which 'does not challenge patriarchal gaze and asymmetric power relations' (Gill \& Orgad, 2017: 30).

Feminist Foucauldian writers (for a review see Elias, Gill, \& Scharff, 2017) have theorised beauty as a disciplinary technology where women become subject to profound surveillance and regulation. Izzie's tight white dress and Louboutin high heels represent a sexualised form of femininity which speaks to the development of the idea of 'technologies of sexiness' (Gill, 2008; Gill \& Orgad, 2015; Radner, 1993, 1999). This is a discursive regime in which women, who were previously expected to bring to marriage their virtue, must now 'embody heterosexuality through the disciplined use of makeup, clothing, exercise, and cosmetic surgery, linking femininity, consumer culture and heterosexuality' (Radner, 1999: 15). Thus Izzie's choice of tight dress and expensive designer high heels link sexualised femininity, consumerism and financial success; performativity constituting her as viable through a form of 'sexual entrepreneurialism' (Harvey \& 
Gill, 2011: 56). Technologies of sexiness can also be linked to ways in which romantic scripts are changing (Radner, 1993) thus in having her husband on stage with her, Izzie remains readable within the heterosexual matrix. Jay makes Izzie the comedy straight guy to his jokes and innuendo and he is mute when she cries about their child as if childcare is not part of his reality. Thus within the heterosexual matrix, hegemonic masculinity is privileged and Izzie must operate within socially intelligible norms of femininity (Butler, 1990).

The technology of sexiness discourse makes me feel frumpy and dull which creates a tension; although as a feminist academic I am intellectually aware of this performativity of gender, I feel a sense of becoming undone by being unreadable within this discourse. As Winch (2015: 233) states, 'managing the body...is the means by which women acquire and display their cultural capital'. I feel that I am perpetuating an element of 'girlfriend gaze' (Winch, 2013), where women and girls police each other's looks and behaviours, through my judgement of the other women. This makes me feel uncomfortable yet I want to blend in and to belong. I worry about my clothes; wanting to appear feminine but not corporate. I feel voyeuristic and as if I am simultaneously one and other; identified as a women but failing in this form of femininity so that avoiding feeling frumpy and dull becomes a form of glamour labour (Wissinger, 2015). It is in this space of discomfort that I argue subjectivities are more visible and regimes of truth and power illuminate how I am constituted and constituting others within the research process.

\section{DISCUSSION}

Within this article, I have used poststructural reflexivity as a form of 'uncomfortable reflexivity' (Dosekun, 2015; Pillow, 2003). The aim of this article was therefore not to provide a validation of 
knowledge, rather to consider the performativity of research which constructs objects and subjects through discourse. Through applying a poststructural approach to reflexivity I have sought to focus on who the researcher is, emphasising how the researcher is produced through discourse (Youdell, 2006). This form of 'uncomfortable reflexivity' seeks to resist regimes of truth (Dosekun, 2015) rather than validate or provide solutions. I drew on the principles of Willig's (2013) Foucauldian Discourse Analysis recognising that while these principles do not constitute a full analysis in the Foucauldian sense through tracing the genealogy of discursive formations, it provides a means of seeing how subject positions have implications for subjectivity and experience. Particularly, it provides insight into what can be said and done from within these subject positions.

Vignettes were selected from my doctoral studies where moments of discomfort arose in the tension that lies where dominant discourse stood uncomfortably next to the way in which I am more commonly construed. Bott (2010) argues that as women academics, our work lives are supposedly 'gender-free', in other words 'womanhood should not be a significant feature of our working identity' (Bott, 2010: 170) yet 'in the field' we are marked in terms of gender. While I would not argue that academia, or indeed any social interaction can be 'gender-free', in these vignettes discourses of masculinity and femininity created a sense of personal discomfort which reconstituted my subjectivity in a way that created a sense of unease.

In the bank vignette, I drew upon Foucauldian Discourse Analysis to trace the shifting discourses from sympathetic women to subordination and powerlessness. In Helena Lui's (2018) autoethnographical account of working as a research fellow at a leadership research centre, she describes the centre director as the 'resident patriarch' instructing women on the appropriateness of their gendered performance. As Lui (2018) argues, the Director represents a form of entrenched patriarchal system which redraws and constrains boundaries of acceptable femininity (Adamson, 
2017; Lewis et al., 2017). I see similarities here in the discomfort that arose when 'Simon' positions himself as the gatekeeper of this feminist research project, thus patriarchal privilege and power relations effect what can be said and done.

In the beauty company vignette, femininity, beauty and aesthetic labour create a disciplinary technology of self where woman are caste as embodying heterosexuality. Combined with the neoliberalism of the NMO this constructs a common sense on gender where messages of individualism, choice and empowerment obscure the reality of the precarious NMO work (Shade, 2018). Within this context I found discomfort through a sense of failing femininity (Gill, 2007; Ringrose \& Walkerdine, 2008) through which I am brought into being (Tyler, 2011). In sensing that I am perpetuating the girlfriend gaze (Winch, 2013) as a judge and critical eye on the women limits what I feel can be said and done leaving me feeling disingenuous. Butler (1990) argues that to be viable, individuals must operate within and maintain socially intelligible norms; to exist as human beings we must be readable within the norms. Thus I argue that these moments of discomfort relate to shifting subjectivities where I feel 'undone' losing my sense of self.

While feminist goals are often associated with challenging metanarratives such as patriarchy, this is rejected by poststructuralist approaches to power. Poststructuralist critique instead allows an interrogation of how power operates to construct our desires and thoughts, in other words, our subjectivities, which can normalise the oppression of some and domination of others (Gannon \& Davies, 2012). Discourses are not abstract but expressed in the very 'matter' of bodies, shaping desires and ways of being in the world (Butler, 2011). So for poststructuralists, the subject is constituted through discourse and therefore at the heart of the operation of power. This raises questions of agency for some feminist writers who argue this therefore removes opportunities for agency and action. However within this article, I offer poststructural reflexivity not as a means of 
agency through freedom from discursive constitution and regulation of subjects (Davies, 2000a, b) but in the opportunity for change through recognising discursive constitution as regimes of truth historically and culturally situated (Gannon \& Davies, 2012).

Poststructural reflexivity presents epistemological and praxis challenges for the researcher. When I reflect back, for example, to the experience of sitting in the Director's office in the bank, I visualise the women sitting quietly and neatly, with hands folded on laps while the Director stands behind his desk which represents a symbol of power and masculinity. This is possibly an adapted recollection; a tableau I have constructed within my memory which represents how I 'read' the performativity of gender in this moment. This demonstrates a challenge for poststructural reflexivity, as Davies et al. (2004: 362) argue, if gaze is constitutive, then in being both the object gazed at and the conductor of the reflexive gaze becomes 'slippery'. Thus the practice of reflexivity should be a site for innovation where we catch ourselves using the old modes of meaning.

\section{CONCLUSION}

Within this article, I extend poststructuralist reflexivity as a way to recognise regimes of truth, power and the discursive regimes through which we become gendered subjects. As Dosekun (2015: 437) argues 'poststructural reflexivity is a matter of deconstructing the performativity of one's research practice, the work of doing so 'is not a matter of looking harder or more closely, but of seeing what frames our seeing - spaces of constructed visibility and incitements to see which constitute power/knowledge' (Lather, 1993: 675). Within this article I draw upon vignettes in which discursive regimes and shifting subjectivities created moments of discomfort in my doctoral research. I argue that poststructural reflexivity offers a methodological window of insight into 
some of these discursive regimes, not of ways of looking harder, but to see what frames our seeing thus providing opportunities to name 'how power intersects with our scholarly work and deconstructing the compelling enticements of accepting the status quo' (Liu, 2018: 14). Overall, the paper broadens our understanding of the methodological challenges of reflexivity through offering poststructural reflexivity as a way to reflect on our ways of seeing and ways of being as feminist researchers. 


\section{References}

Adamson, M. 2017. Postfeminism, neoliberalism and a 'successfully' balanced femininity in celebrity CEO autobiographies. Gender, Work \& Organization, 24(3): 314-327.

Biggart, N. W. 1989. Charismatic capitalism: direct selling organizations in America. Chicago: University of Chicago Press.

Bott, E. 2010. Favourites and others: reflexivity and the shaping of subjectivities and data in qualitative research. Qualitative Research, 10(2): 159-173.

Bruni, A., Gherardi, S., \& Poggio, B. 2005. Gender and entrepreneurship. [electronic resource] : an ethnographic approach: London ; New York : Routledge, 2005.

Burr, C. 2015. Social Constructionism. Hove. East Sussex.: Routledge.

Butler, J. 1990. Gender trouble : feminism and the subversion of identity New York: Routledge.

Butler, J. 1997. Performative acts and gender constitution: An essay in phenomenological and feminist theory. In K. Conboy, N. Medina, \& S. Stanbury (Eds.), Writing on the body: Female embodiment and feminist theory: 401-417. New York: Columbia University press.

Butler, J. 2004. Undoing gender: New York ; London : Routledge, 2004.

Butler, J. 2011. Bodies that matter. [electronic resource] : on the discursive limits of "sex": Abingdon, Oxon ; New York, NY : Routledge, c2011.

Cunliffe, A., \& Haynes, K. 2011. Tensions in (re)presenting the self in reflexive autoethnographical research. Qualitative Research in Organizations and Management: An International Journal(2): 134.

Davies, B. 2000a. A body of writing. Walnut Creek, CA.: AltaMira Press.

Davies, B. 2000b. (in)scribing body/landscape relations. Walnut Creek, CA: AltaMira Press.

Davies, B., Browne, J., Gannon, S., Honan, E., Laws, C., Mueller-Rockstroh, B., \& Petersen, E. B. 2004. The Ambivalent Practices of Reflexivity. Qualitative Inquiry, 10(3): 360-389.

Davies, B., Browne, J., Gannon, S., Hopkins, L., McCann, H., \& Wihlborg, M. 2006. Constituting the feminist subject in poststructuralist discourse. Feminism \& Psychology, 16(1): 87-103.

Davies, B., \& Gannon, S. 2011. Feminism/poststructuralism. In C. Lewin, \& B. Somekh (Eds.), Theory and methods in social research: 312-319. London: Sage.

Davies, B., \& Harre, R. 1999. Positioning and personhood. In R. Harre, \& v. Langenhove (Eds.), Positioning theory, 2nd ed.: 32-52.

Dosekun, S. 2015. "Hey, You Stylized Woman There": An Uncomfortable Reflexive Account of Performative Practices in the Field. Qualitative Inquiry, 21(5): 436.

Elias, A. S., Gill, R., \& Scharff, C. 2017. Aesthetic Labour: Beauty Politics in Neoliberalism. In A. S. Elias, R. Gill, \& C. Scharff (Eds.), Aesthetic Labour: Rethinking Beauty Politics in Neoliberalism: 3-49. London: Palgrave Macmillian.

Erickson, F. 1986. Qualitative methods in research on teaching. In M. Witrock (Ed.), Handbook of research on teaching, 3rd ed.: 119-161. New York: Macmillan.

Finlay, L. 2002. Negotiating the swamp: The opportunity and challenge of reflexivity in research practice. Qualitative Research, 2(2): 209-230.

Foucault, M. 2008. The birth of biopolitics: Lectures at the College de France 1978-1979. New York: Palgrave Macmillan.

Gannon, S., \& Davies, B. 2012. Postmodern, Post-structural, and Critical Theories. In S. N. Hesse-Biber (Ed.), Handbook of Feminist Research: Theory and Praxis. Thousand-Oak, CA.: Sage.

Gherardi, S. 1994. The Gender We Think, the Gender We Do in Our Everyday Organizational Lives. Human Relations, 47(6): 591-610.

Gill, R. 2007. Postfeminist media culture. European Journal of Cultural Studies, 10(2): 147-166. 
Gill, R. 2008. Empowerment/Sexism: Figuring female sexual agency in contemporary advertising. Feminism Psychology, 18(1): 35-60.

Gill, R., \& Orgad, S. 2015. The Confidence Cult(ure). Australian Feminist Studies, 30(86): 324-344.

Gill, R., \& Orgad, S. 2017. Confidence culture and the remaking of feminism. New Formations(91): 16-34. Gond, J. P., Cabantous, L., Harding, N., \& Learmonth, M. 2016. What Do We Mean by Performativity in Organizational and Management Theory? The Uses and Abuses of Performativity. International Journal of Management Review, 18(4): 440-463.

Harvey, L., \& Gill, R. 2011. Spicing It Up: Sexual Entrepreneurs and The Sex Inspectors. In R. Gill, \& C. Scharff (Eds.), New Femininities: Postfeminism, Neoliberalism and Subjectivity: 52-67. London: Palgrave.

Humphreys. 2005. Getting Personal: Reflexivity and Autoethnographic Vignettes. Qualitative Inquiry, 11(6): 840-860.

Kanter, R. M. 1977. Men and Women of the Corporation. New York: Basic Books.

Kelan, E. K. 2010. Gender Logic and (Un)doing Gender at Work. Gender, Work \& Organization, 17(2): 174-194.

Kelan, E. K. 2013. The becoming of business bodies: Gender, appearance, and leadership development. Management Learning, 44(1): 45-61.

Kendall, G., \& Wickham, G. 1999. Using Foucault's Methods. London, England, United Kingdom: SAGE Publications, Ltd.

Lather, P. 1993. Fertile Obsession: Validity after Poststructuralism. The Sociological Quarterly, 34(4): 673-693.

Lewis, P. 2013. The Search for an Authentic Entrepreneurial Identity: Difference and Professionalism among Women Business Owners. Gender, Work \& Organization, 20(3): 252-266.

Lewis, P., Benschop, Y., \& Simpson, R. 2017. Postfeminism, Gender and Organization. Gender, Work \& Organization, 24(3): 213-225.

Liu, H. 2018. An embarrassment of riches: The seduction of postfeminism in the academy. Organization, 0(0): 1350508418763980.

Lynch, M. 2000. Against Reflexivity as an Academic Virtue and Source of Privileged Knowledge. Theory, Culture \& Society, 17(3): 26-54.

Martin, P. Y. 2003. "Said and Done" versus "Saying and Doing": Gendering Practices, Practicing Gender at Work. Gender and Society, 17(3): 342-366.

Parker, I. 1992. Discourse Dynamics: Critical Analysis for Social and Individual Psychology. London: Routledge.

Parker, I. 1994. Reflexive research and the grounding of analysis: Social psychology and the psy-complex. Journal of Community \& Applied Social Psychology, 4(4): 239-252.

Pillow, W. S. 2003. Confession, catharsis, or cure? Rethinking the uses of reflexivity as methodological power in qualitative research. International Journal of Qualitative Studies in Education, 16(2): 175-196.

Poggio, B. 2006. Editorial: Outline of a Theory of Gender Practices. Gender, Work \& Organization, 13(3): 225-233.

Pullen, A. 2006. Gendering the Research Self: Social Practice and Corporeal Multiplicity in the Writing of Organizational Research. 13(3): 277-298.

Pullen, A., \& Knights, D. 2007. Editorial: Undoing Gender: Organizing and Disorganizing Performance. Gender, Work \& Organization, 14(6): 505-511.

Radner, H. 1993. Pretty is as pretty does: Free enterprise and the marriage plot. In H. Collins, \& A. Preacher (Eds.), Film Theory Goes to the Movies: 79-97. New York: Routledge.

Radner, H. 1999. Introduction: Queering the Girl. In H. Radner, \& M. Luckett (Eds.), Swinging Single: Representing Sexulaity in the 1960's: 1-17. Minneapolis: University of Minnesota Press. 
Reinharz, S., \& Davidman, L. 1992. Feminist methods in social research: Oxford : Oxford University Press, 1992.

Ringrose, J., \& Walkerdine, V. 2008. Regulating The Abject. Feminist Media Studies, 8(3): 227-246.

Salih, S. 2002. Judith Butler. Abingdon, Oxon.: Routledge.

Shade, L. R. 2018. Hop to it in the gig economy: The sharing economy and neo-liberal feminism. International Journal of Media \& Cultural Politics, 14(1): 35-54.

Simpson, R., \& Lewis, P. 2007. Voice, Visibility and the Gendering of Organizations. Basingstoke: Palgrave Macmillan.

Sullivan, K. R., \& Delaney, H. 2017. A femininity that 'giveth and taketh away': The prosperity gospel and postfeminism in the neoliberal economy. Human Relations, 70(7): 836-859.

Tyler, I. 2011. New femininities: postfeminism, neoliberalism, and subjectivity. Houndmills, Basingstoke, Hampshire: Palgrave Macmillan.

Tyler, M. 2012. Postmodern Feminism and Organization Studies: A Marriage of Inconvenience. In E. Jeanes, D. Knights, \& P. Yancey-Martin (Eds.), Handbook of Gender, Work and Organization. Chichester: Wiley.

Weedon, C. 1997. Feminist Practice and Poststructuralist Theory (2nd ed.). Oxford: Blackwell.

West, C., \& Zimmerman, D. 1987. Doing Gender. Gender and Society, 1(2): 125-151.

Williams, C., Muller, C., \& Kilanski, K. 2012. Gendered organizations in the new economy. Gender \& Society, 26(4): 549-573.

Willig, C. 2013. Foucauldian discourse analysis. In C. Willig (Ed.), Introducing Qualitative Research in Psychology, 3rd ed. Maidenhead: McGraw-Hill.

Winch, A. 2013. Girlfriends and Postfeminist Sisterhood. Basingstoke: Palgrave Macmillan.

Winch, A. 2015. Brand Intimacy, Female Friendship and Digital Surveillance. New Formations, 84: 228245.

Wissinger, E. 2015. The Year's Model: Fashio, Media, and the Making of Glamour. New York: NYU Press.

Wolf, M. 1990. A Thrice Told Tale. Stanford, CA.: Stanford University Press.

Wolfinger, N. H. 2002. On writing fieldnotes: collection strategies and background expectancies. Qualitative Research, 2(1): 85-95.

Youdell, D. 2006. Impossible bodies, impossible selves: Exclusions and student subjectivities. Dordrecht, the Netherlands: Spronger Verlag. 